\title{
A Dynamic Competitive Environment and Shifting Management Paradigms: Implications for Marketing Public Transit Services
}

\author{
J. Joseph Cronin, Jr., Florida State University \\ Roscoe Hightower, Jr., University of Akron
}

\begin{abstract}
This article reports on the results of a telephone survey of 352 commuters who reside in a suburban area and work in a major city. Results indicate that the commuters are well educated and well paid. They also suggest that much of what has passed for marketing strategies in the transit industry has been ineffective at best. Solutions for the dilemma are identified and considered.

\section{Introduction}

The problems of organizations in decline are neither novel nor new. The product life cycle' has been offered as an explanation of this process, yet whole industries have fallen prey. American railroad firms did not recognize how their businesses were affected by changing economic and demographic environments and the emergence of airlines as a competitor. They have yet to regain market share, even while their European counterparts have retained their viability. The current analogy in the United States is public transit. Though it is widely acknowledged and documented that the public transit industry is in cri-
\end{abstract}


sis, it has been slow to respond (Daft, Lengel, and Perdue 1998).

The crisis facing public transit is not unique. In the past two decades many industries have faced similar problems. Banking, insurance, retailing, and the defense industries all have experienced the pressures of government regulation, product obsolescence, information overload, changing family structures, and two-income households that have drastically intensified competitive pressures. As a result, firms in these industries have used restructuring, reengineering, mergers, acquisitions, joint ventures, and a variety of consumer-based strategic approaches to redefine their position in the marketplace (Daft, Lengel, and Perdue 1998).

In each case, success was brought about by the organization's willingness to embrace change. Managers had to realize that old methods and products were no longer acceptable alternatives in the new realities of the marketplace. Business paradigms - an organization's way of thinking, perceiving, and understanding its role in the marketplace (Daft, Lengel, and Perdue 1998)shifted. The crisis inherent today in the public transit industry is very much rooted in these pressures and the need for a "paradigm shift."

\section{Background}

In an effort to compete with the automobile, transit agencies have turned to marketing to increase the perceived value of their services. Rideshare, transit voucher, employee pass, and transportation coordinator programs all have had some success. However, the market orientation of public transit firms still lags behind the private sector. Being market oriented simply means maintaining a viable fit between an organization's objectives, skills, and resources, and its changing market opportunities (Kotler 1997). While there have been welldocumented demographic, economic, and technological changes in U.S. markets, has the basic product offered by public transit organizations changed in the last decade? The last two decades? The last half century?

Although the programs mentioned above have met with some success, most have done so largely by adjusting the monetary cost of commuting. Price discounts are a short-term incentive only. Many larger issues still confront public transit properties. Is the service package, the bundle of benefits offered by 
public transit services, what today's commuter needs and wants? How do public policy issues such as air quality control and traffic congestion affect commuters' decisions?

Answers to these questions, as with all marketing decisions, start with the consumer. The study reported here examined the expectations of the new-millennium public transit consumer. By searching for new answers to old questions, the researchers hoped to identify and encourage some of the needed paradigm shifts.

\section{The Research Design}

In order to explore the identified research questions, the researchers sought the cooperation of a transit agency that had an ongoing marketing effort designed to increase ridership in an area experiencing air quality and traffic congestion problems. This was necessary to ensure that the sample population would have some knowledge of the environmental factors that provide a motivation to use public transit and the available public transit alternatives, even if they were not transit users. The researchers secured the assistance of a public transit property that was interested in the level of ridership on its bus routes connecting suburban residential areas with a major urban retail and business employment corridor. The agency is located in a major (top 10 in population) urban area that has welldocumented air quality and traffic congestion problems.

\section{Method}

The following sections describe the survey methodology used in the study.

Survey Participants. A random sample was contacted by telephone ( 352 completed calls). Individuals employed in the area served by the transit property's buses were identified as the appropriate respondents. Because there is little motivation to use the local public transit service, more than 17,000 calls had to be made in order to identify qualified respondents. Each respondent answered questions during an interview of approximately eight minutes. Since commuters into the area come from any of four counties in the metro area surveyed, an effort was made to stratify the selection process to reflect the relative size of each county. Screening questions were used to ensure that respon- 
dents met the predetermined qualifications: age 18, full-time employee in the area of interest, and a resident of one of the four counties served by the transit property. The sample characteristics are identified in Table 1. In general, the sample characteristics indicate that those employed in the area are generally well-educated, middle- to upper-middle-income level, white-collar workers. Respondents tend to classify themselves as white/Caucasian; there are slightly more females than males, and they are approximately normally distributed in age. The demographic profile of the respondents appears consistent with the fact that the major employers in the area are upscale retail outlets and professional offices.

Survey Implementation. Survey respondents were randomly selected from a commercial computer-based telephone data system. The staff of the Florida State University Marketing Institute conducted the telephone interviews. All interviewers had extensive training and were supervised.

Survey Instrument. The questionnaire was developed specifically to assess current travel patterns, mode choice, and the potential impact of external events or attitudes toward travel behavior. The instrument was developed after consultation with the local transit property and a review of the existing research on attitudes toward alternative transportation modes.

Survey Processing. The telephone interviews were completed during a six-week period during the fall. The data were inspected and entered into computer readable files. Analysis was undertaken using SPSS 8.0 software.

\section{Results}

Five specific questions were investigated in this study:

- How important is the commuting decision to consumers?

- What are the best solutions to current transportation problems?

- What are the characteristics of existing home-work-home commute patterns?

- What would encourage the use of public transit?

- Which "businesses" should public transit agencies consider part of their mission? 


\begin{tabular}{|c|c|c|}
\hline \multicolumn{3}{|c|}{$\begin{array}{c}\text { Table } 1 \\
\text { Telephone Survey Respondent Characteristics }\end{array}$} \\
\hline Gender & Frequency & Percentage \\
\hline Male & 157 & 44.9 \\
\hline Female & 193 & 55.1 \\
\hline Age & Frequency & Percentage \\
\hline Under 30 & 62 & 17.8 \\
\hline $30-34$ & 58 & 16.6 \\
\hline $35-39$ & 65 & 18.6 \\
\hline $40-49$ & 99 & 28.4 \\
\hline 50 and older & 58 & 16.6 \\
\hline Refused & 7 & 2.0 \\
\hline Race & Frequency & Percentage \\
\hline White & 281 & 81.7 \\
\hline African-American & 50 & 14.5 \\
\hline Asian & 3 & 0.9 \\
\hline Spanish or Hispanic & 3 & 0.9 \\
\hline Other & 7 & 2.0 \\
\hline Don't know & 0 & 0.0 \\
\hline Refused & 6 & \\
\hline Income & Frequency & Percentage \\
\hline Less than $\$ 20,000$ & 9 & 2.6 \\
\hline$\$ 20,000-\$ 30,000$ & 26 & 7.5 \\
\hline$\$ 30,001-\$ 40,000$ & 39 & 11.3 \\
\hline$\$ 40,001-\$ 50,000$ & 44 & 12.7 \\
\hline$\$ 50,001-\$ 70,000$ & 66 & 14.1 \\
\hline Over $\$ 70,000$ & 111 & 32.1 \\
\hline Refused & 51 & \\
\hline Education & Frequency & Percentage \\
\hline Eleven years or less & 1 & 0.3 \\
\hline Completed high school & 61 & 17.6 \\
\hline Business or technical school & 7 & 2.0 \\
\hline Some college & 82 & 23.7 \\
\hline Completed college & 139 & 40.2 \\
\hline Graduate or professional school & 56 & 16.2 \\
\hline Occupation & Frequency & Percentage \\
\hline Executive/Managerial/Professional & 135 & 38.9 \\
\hline Administrative/Technical & 60 & 17.3 \\
\hline Clerical/Secretarial & 32 & 9.2 \\
\hline Manufacturing/Laborer/Operator & 23 & 6.6 \\
\hline Sales/Service & 51 & 14.7 \\
\hline Other & 46 & 13.3 \\
\hline Refused & 2 & \\
\hline
\end{tabular}




\section{Importance of Public Transit Issues}

In order to develop a comprehensive understanding of the attitude of the area's commuters about the importance of public transit, respondents were asked to respond to several statements and questions. Their responses revealed the importance of transit service to the quality of life enjoyed by the area's commuters. Sixty-nine percent of the respondents rated the development of an effective public transit system as very important, even if they never used the service. Another 21 percent considered the issue important (Table 2). The rationale for this ranking by the respondents appears obvious. Nearly 77 percent suggested that traffic congestion has worsened in the area during the past year (Table 3$)$. More than half $(51.6 \%)$ rated their commute to work as more stressful than the other aspects of their workday (Table 4). Nearly 94 percent of the respondents agree that traffic congestion is a serious problem in the area (Table 5) and 88.7 percent agree that traffic congestion has a personal effect on their life (Table 6). Over 90 percent $(91.7 \%)$ of those completing the survey also believe that the area's traffic congestion could be greatly reduced if some people cut back on their car trips (Table 7).

One obvious implication of these results is that transit properties might be well advised to make potential users aware of the benefits of using public transit. Marketing efforts (e.g., advertising messages) by transit organizations should reinforce the idea that having a public transit system is important and it should be used because using public transit reduces congestion and stress.

\begin{tabular}{|c|c|c|}
\hline $\begin{array}{l}\text { Impor } \\
\text { Question: How important is it to develc } \\
\text { use the service? }\end{array}$ & $\begin{array}{r}\text { Table } 2 \\
\text { nce of Pul } \\
\text { public transp }\end{array}$ & nunity even if you never \\
\hline Response & Frequency & Percentage \\
\hline Very important & 238 & 69.2 \\
\hline Somewhat important & 71 & 20.6 \\
\hline Neither important nor unimportant & 2 & 0.6 \\
\hline Somewhat unimportant & 12 & 3.5 \\
\hline Very unimportant & 21 & 6.1 \\
\hline
\end{tabular}




\section{Table 3 \\ Traffic Congestion}

Question: Generally, in the past year, traffic congestion in the area has:

\begin{tabular}{lcc|} 
Response & Frequency & Percentage \\
\hline Gotten worse & 259 & 76.9 \\
Gotten better & 11 & 3.3 \\
Stayed about the same & 64 & 18.9 \\
Don't know & 3 & 0.9 \\
\hline
\end{tabular}

\section{Table 4 \\ Work Commute Stress}

Question: Compared to other aspects of your workday, how stressful do you find your commute to work? (Please answer from 1-5 with 1 being much more stressful and 5 being much less stressful.)

\begin{tabular}{|cccc|}
\hline Response & & Frequency & Percentage \\
\hline Much more stressful & 1 & 89 & 25.5 \\
& 2 & 91 & 26.1 \\
& 3 & 88 & 25.2 \\
& 4 & 52 & 14. \\
Much less stressful & 5 & 29 & 8.3 \\
\hline
\end{tabular}

The link between single-occupancy vehicle (SOV) commutes and air quality is acknowledged as 83.5 percent of the respondents agreed that air pollution would be greatly reduced if some people cut back on their number of car trips (Table 8). In addition, 62.8 percent agreed that air pollution is a serious problem in the area (Table 9). However, less than half of the respondents (49.6\%) believe they are personally affected by the area's poor air quality (Table 10).

Apparently, consumers have difficulty seeing the effects of poor air quality, probably because of the long-term nature of the impact. Thus, public transit marketers must make education a key tool in their advertising campaigns.

\section{Solutions to the Area's Transportation Problems}

Based on the survey results, three basic alternatives were identified: (1) build more highways, (2) rideshare programs, and (3) better public transit. 


\begin{tabular}{|lcc|}
\hline \multicolumn{2}{|c|}{ Table 5} \\
Traffic Congestion-Seriousness of Problem \\
Question: Traffic congestion is a serious problem in the area. \\
Response & Frequency & Percentage \\
\hline Strongly agree & 227 & 65.0 \\
Agree & 101 & 28.9 \\
Neutral & 13 & 3.7 \\
Disagree & 7 & 2.0 \\
Strongly disagree & 1 & 0.3 \\
\hline
\end{tabular}

\begin{tabular}{|ccc|}
\hline \multicolumn{3}{|c|}{ Table 6 } \\
Question: I am personally affected by \\
Response & Fraffic congestion. & \\
\hline Strongly agree & 178 & Percentage \\
Agree & 131 & 51.1 \\
Neutral & 19 & 37.6 \\
Disagree & 18 & 5.5 \\
Strongly disagree & 2 & 5.2 \\
\hline
\end{tabular}

\section{Table 7 \\ Traffic Congestion Reduction and Car Trips}

Question: Traffic congestion would be greatly reduced if some people cut back on how often they make car trips.

\begin{tabular}{|lcc|}
\multicolumn{1}{c}{ Response } & Frequency & Percentage \\
\hline Strongly agree & 144 & 41.4 \\
Agree & 175 & 50.3 \\
Neutral & 14 & 4.0 \\
Disagree & 14 & 4.0 \\
Strongly disagree & 1 & 0.3 \\
\hline
\end{tabular}




\section{Table 8}

\section{Air Pollution Reduction}

Question: Air pollution would be greatly reduced if some people cut back on how often they make car trips.

\begin{tabular}{|lcc|}
\hline \multicolumn{1}{c}{ Response } & Frequency & Percentage \\
\hline Strongly agree & 108 & 31.3 \\
Agree & 180 & 52.2 \\
Neutral & 31 & 9.0 \\
Disagree & 20 & 5.8 \\
Strongly disagree & 6 & 1.7 \\
\hline
\end{tabular}

\section{Table 9}

\section{Air Pollution Evaluation}

Question: Air pollution is a serious problem in the area.

\begin{tabular}{|lcc|} 
Response & Frequency & Percentage \\
\hline Strongly agree & 71 & 23.7 \\
Agree & 117 & 39.1 \\
Neutral & 32 & 10.7 \\
Disagree & 51 & 17.1 \\
Strongly disagree & 28 & 9.4 \\
\hline
\end{tabular}

\section{Table $\mathbf{1 0}$}

\section{Air Pollution's Effect on Me}

Question: I am affected personally by air pollution.

\begin{tabular}{|lcc|}
\multicolumn{1}{c}{ Response } & Frequency & Percentage \\
\hline Strongly agree & 42 & 12.7 \\
Agree & 122 & 36.9 \\
Neutral & 51 & 15.4 \\
Disagree & 91 & 27.5 \\
Strongly disagree & 25 & 7.6 \\
\hline
\end{tabular}


Predictably, the most frequent response (33.8\%) was that some combination of the three alternatives represented the best solution to the area's current transportation problems (Table 11). However, the most popular solution of the three was a better public transit system (27.7\%). Building more highways was the least popular option (9.0\%).

\begin{tabular}{|lcc|}
\multicolumn{3}{c|}{ Table 11 } \\
Solutions for Transit Problems \\
$\begin{array}{l}\text { Question: Which of the following would you say is the best solution to the area's current transporta- } \\
\text { tion problems? (Choose all that apply.) }\end{array}$ & Percentage \\
\hline Response & Frequency & 9.0 \\
\hline Build more highways & 42 & 16.1 \\
Rideshare programs & 75 & 27.7 \\
Better public transit & 129 & 33.8 \\
All of the above & 157 & .4 \\
No problems exist & 2 & 1.1 \\
Not sure & 5 & 11.8 \\
Other & 55 & \\
\hline
\end{tabular}

Table 12 summarizes the relationship between respondents' opinions regarding the area's air quality and traffic congestion and the best solution to the area's current transportation problems. Of the three primary options, building a better public transportation system is the most popular choice when air quality or traffic congestion is considered a serious problem or personally impacting. However, an even greater number of respondents feel the best solution involves some combination of the three options.

While the number calling for a combination strategy appears to suggest a preference for the auto as a means of commuting, this still represents a positive for the transit industry. Highway and rideshare programs are part of the old transportation paradigm. Replacing old transit systems with something better is a move toward a paradigm shift. While "better public transit" is a vague solution, it can be interpreted as a call for something new. It is a call the public transit industry needs to answer. However, before answers can be formulated, the problem needs to be understood. To that end, the researchers next examined the nature of the area's commutes. 


\begin{tabular}{|c|c|c|c|c|c|c|c|}
\hline \multicolumn{7}{|c|}{$\begin{array}{l}\text { Table } 12 \\
\text { Comparison of Air and Traffic Opinions } \\
\text { and Solutions to the Area's Transportation Problems } \\
\text { (in percent) }\end{array}$} & \multirow[b]{2}{*}{ Other } \\
\hline $\begin{array}{l}\text { Solution } \longrightarrow \\
\text { Opinion }\end{array}$ & $\begin{array}{l}\text { Build } \\
\text { Highways }\end{array}$ & $\begin{array}{l}\text { Ride } \\
\text { Together }\end{array}$ & $\begin{array}{l}\text { Better Public } \\
\text { Transit }\end{array}$ & $\begin{array}{l}\quad \text { All of } \\
\text { These Options }\end{array}$ & $\begin{array}{l}\text { There Are } \\
\text { No Problems }\end{array}$ & $\begin{array}{l}\text { Not } \\
\text { Sure }\end{array}$ & \\
\hline Air pollution is serious & $8.0 \% \mathrm{a}$ & $26.1 \%$ & $39.4 \%$ & $44.7 \%$ & $0.0 \%$ & $1.6 \%$ & $17.6 \%$ \\
\hline I'm affected by air pollution & 9.8 & 26.2 & 41.5 & 40.2 & 0.0 & 0.6 & 12.1 \\
\hline $\begin{array}{l}\text { Air pollution reduced by } \\
\text { fewer trips }\end{array}$ & 10.1 & 23.3 & 38.2 & 46.9 & 0.0 & 0.3 & 15.6 \\
\hline Traffic congestion is a problem & 11.0 & 20.7 & 37.5 & 45.4 & 0.6 & 0.9 & 16.2 \\
\hline $\begin{array}{l}\text { I'm personally affected by traffic } \\
\text { congestion }\end{array}$ & 12.3 & 22.0 & 36.9 & 45.0 & 0.3 & 1.3 & 16.5 \\
\hline Traffic reduced by fewer car trips & 11.6 & 22.2 & 37.2 & 45.9 & 0.3 & 0.9 & 15.9 \\
\hline I can reduce my car trips & 3.9 & 28.6 & 32.5 & 46.8 & 1.3 & 1.3 & 15.6 \\
\hline
\end{tabular}

${ }^{a}$ Represents the percent of individuals who strongly agree or agree with the opinion who suggest that the appropriate solution is as noted. In this case, 8 percent of those who strongly agree or agree that air pollution is a serious problem in the area suggest that the best solution is building additional highways. Rows may sum to more than 100 percent because respondents were allowed to choose multiple solutions.

\section{Characteristics of the Home-Work-Home Commute}

Table 13 suggests that the vast majority of the area's commutes are made in SOVs, as 81.0 percent of the respondents drive alone to work five days a week. The mean commute time to work is 34.9 minutes (Table 14) and the reverse commute averages 37.6 minutes (Table 15). Most commuters travel directly to work (63.5\% travel directly to work five or more days per week); however, only 29.9 percent return directly home after work a like number of times (Tables 16 and 17). In addition, 67.2 percent of the sample uses their car during the workday at least twice per week (Table 18). Thus, it is not surprising that only 21.9 percent of the respondents indicate that they are able to reduce the number of car trips made to work each week (Table 19).

These results point out three distinct factors that must be considered in the transit industry's strategic initiatives:

1. On average, over an hour a day is spent commuting to and from this area. This is a significant "cost" to commuters. 


\section{Table 13 \\ Area Commute Patterns}

Question: The next set of questions address how you get to work each day. Please indicate (on average) how many days per week you travel to work by the following means of transportation:

\begin{tabular}{ccccccccc}
$\begin{array}{c}\text { Number of } \\
\text { Days }\end{array}$ & $\begin{array}{c}\text { Drive } \\
\text { Alone }\end{array}$ & Carpool & Vanpool & $\begin{array}{c}\text { Urban } \\
\text { System }\end{array}$ & Walk & Bicycle & XXX & Other \\
\hline 1 & 0.9 & 20.0 & 100 & 0 & 0 & 100 & 33.3 & 100 \\
2 & 3.0 & 15.0 & 0 & 100 & 100 & 0 & 33.3 & 0 \\
3 & 5.1 & 20.0 & 0 & 0 & 0 & 0 & 0 & 0 \\
4 & 2.7 & 7.5 & 0 & 0 & 0 & 0 & 0 & 0 \\
5 & 81.0 & 32.5 & 0 & 0 & 0 & 0 & 0 & 0 \\
6 & 6.0 & 2.5 & 0 & 0 & 0 & 0 & 33.3 & 0 \\
7 & 1.2 & 2.5 & 0 & 0 & 0 & 0 & 0 & 0 \\
$\mathrm{~N}$ & 332 & 40 & 1 & 1 & 2 & 1 & 3 & 1 \\
Mean & 4.8 & 3.0 & 1.0 & 2.0 & 2.0 & 1.0 & 3.0 & 1.0 \\
\hline
\end{tabular}

\section{Table 14 \\ Home-to-Work Commute Time}

Question: About how long does the trip from home to work usually take?

\begin{tabular}{|lcc|}
\multicolumn{1}{c}{ Response } & Frequency & Percentage \\
\hline Less than 20 minutes & 65 & 18.6 \\
$20-29$ minutes & 60 & 17.2 \\
$30-39$ minutes & 88 & 25.2 \\
$40-59$ minutes & 87 & 24.9 \\
60 or more minutes & 49 & 14.0 \\
Mean $=34.9$ & & \\
\hline
\end{tabular}

\section{Table 15}

\section{Work-to-Home Commute Time}

Question: About how long does the trip from work to home usually take?

Response

Less than 20 minutes

20-29 minutes

30-39 minutes

40-59 minutes

60 or more minutes

Mean $=37.6$
Frequency

Percentage

22.3

33

94

26.9

80

22.8

65

18.6 


\section{Table 16 \\ Days per Week Making Nonstop Trip to Work}

Question: In a typical week, how many days do you go directly to work withoutmaking any stops?

Response

0

1

2

3

4

5

6

Mean $=4.17$
Frequency

35

8

14

23

47

212

11
Percentage

10.0

2.3

4.0

6.6

13.4

60.6

3.1

\section{Table 17}

\section{Days per Week Making Nonstop Trip Home from Work}

Question: In a typical week, how many days do you return directly home from work without making any stops?

\begin{tabular}{|ccc|} 
Response & Frequency & Percentage \\
\hline 0 & 37 & 10.7 \\
1 & 22 & 6.3 \\
2 & 30 & 8.6 \\
3 & 72 & 20.7 \\
4 & 82 & 23.6 \\
5 & 99 & 28.5 \\
6 & 5 & 1.4 \\
\hline
\end{tabular}

\section{Table 18 \\ Nonwork Car Usage}

Question: Not counting your trip to and from work, how many times, on average, do you use your car during the workday for things such as shopping, running errands, off-site business meetings, or lunch?

\begin{tabular}{|lcc|}
\multicolumn{1}{c}{ Response } & Frequency & Percentage \\
\hline Never & 56 & 16.0 \\
Once a week or less & 59 & 16.9 \\
$2-4$ times a week & 101 & 28.9 \\
Once a day & 71 & 20.3 \\
Twice a day & 19 & 5.4 \\
More than twice a day & 44 & 12.6 \\
\hline
\end{tabular}

Vol. 3, No. 1, 2000 


\section{Table 19}

\section{Ability to Reduce Work Commute}

Question: I am able to reduce the number of car trips to work I make each week.

\begin{tabular}{|lcc|}
\multicolumn{1}{c}{ Response } & Frequency & Percentage \\
\hline Strongly agree & 17 & 4.9 \\
Agree & 59 & 17.0 \\
Neutral & 32 & 9.2 \\
Disagree & 207 & 59.5 \\
Strongly disagree & 33 & 9.5 \\
\hline
\end{tabular}

2. The reverse commute is more problematic for public transit operators. Strategies to accommodate multiple-task reverse commutes need to be a priority in the strategic planning initiatives of public transit agencies.

3. Most commuters make personal and work-related trips during the workday. To effectively compete, public transit must accommodate these trips.

In summary, these three factors suggest that commuting is time consuming and that reverse commutes (i.e., work-to-home) are multitask oriented. One motivation to use public transit might be the ability to make productive use of the time spent commuting. In area studies, over an hour a day could be added to the workday, leisure activities, or relaxation if public transit is utilized. The difficulty is overcoming the need for the flexibility provided by a car. Research can identify the most common tasks performed at lunch or on reverse commutes. Some transit properties have studied these tasks and are adding child care, dry cleaning, food, and workout facilities at selected stations.

\section{Encouraging Alternative Forms of Transportation}

Table 20 identifies the commute alternatives that respondents would consider using at least once a week, if they were available. The alternative most frequently identified as one that would be used, if available, was carpooling $(52 \%)$, closely followed by rail service $(50.3 \%)$. The bus system offered by the cooperating transit agency (suburban system bus in Table 20) was the third most frequently identified option $(32.4 \%)$. Of these three, only rail service is not currently available in the area studied. 


\section{Table 20 \\ Commute Alternatives}

Question: If available, which of the following means of commuting would you consider using at least once per week? (Circle all that apply.)

\begin{tabular}{|lcc|}
\multicolumn{1}{c}{ Mode } & Frequency & Percent of Respondents \\
\hline Walk & 95 & 27.0 \\
Carpool & 183 & 52.0 \\
Vanpool & 99 & 28.1 \\
Suburban system bus & 114 & 32.4 \\
Bicycle & 54 & 15.3 \\
Urban system train & 177 & 50.3 \\
Urban system bus & 110 & 31.3 \\
Other & 4 & 1.1 \\
None & 52 & 14.8 \\
\hline
\end{tabular}

Only one in five respondents $(20.3 \%)$ indicated that they could never use an alternative commuting option because of their job requirements or lifestyle (Table 21). This is also a positive for the industry. The most frequently identified incentive to use an alternative form of transportation was a guaranteed ride home (76.5\%), followed closely by financial incentives (73.5\%) (Table 22). More than two-thirds of the sample $(67.2 \%)$ indicated that they would commute by transit more often if their employer offered a free or subsidized pass (Table 23). The implication of these findings for transit marketers are rather obvious: provide incentives to use public transit. Many transit properties, in fact, already have pursued such programs with major employers in their service areas.

Disincentives are also important and 85.1 percent of the respondents found it not difficult at all to find a convenient parking space every workday (Table 24). In fact, 92.3 percent parked in a lot or garage at their worksite (Table 25). In contrast to the door-to-door convenience of the SOV commute, for more than two-thirds of the sample (68.9\%) the nearest bus stop to their residence is three or more blocks away (Table 26). In contrast, 70.6 percent have a stop within two blocks of their worksite (Table 27). 


\section{Table 21 \\ Days Could Use a Commute Alternative (weekly)}

Question: Given the requirements of your job and your lifestyle, how many days per week could you use the commute alternatives selected above?

\begin{tabular}{|ccc|} 
Mode & Frequency & Percent of Respondents \\
\hline 0 & 61 & 20.3 \\
1 & 22 & 7.3 \\
3 & 43 & 14.3 \\
4 & 56 & 18.6 \\
5 & 10 & 3.3 \\
6 & 102 & 33.9 \\
7 & 4 & 1.3 \\
Mean $=2.89$ & 3 & 1.0 \\
\hline
\end{tabular}

\section{Table 22}

\section{Reasons to Use a Commute Alternative}

Question: Which of the following would encourage you to use alternative transportation in general more often to commute each day?

\begin{tabular}{|llll|}
\multicolumn{1}{c}{ Reason } & Yes & No & $N$ \\
\hline Parking fees & 46.7 & 53.3 & 334 \\
Financial incentives & 73.5 & 26.2 & 340 \\
More flexible work hours & 53.8 & 46.2 & 340 \\
Guaranteed ride home & 76.5 & 23.5 & 344 \\
Showers/lockers & 28.2 & 71.8 & 326 \\
Use of company vehicle & 36.3 & 63.7 & 328 \\
Frequent and direct bus service & 59.8 & 40.2 & 336 \\
Shopping and services & 50.5 & 49.5 & 333 \\
Other & 1.1 & 98.9 & 4 \\
None of the above & 8.0 & 92.0 & 28 \\
\hline
\end{tabular}




\section{Table 23 \\ Use of Commuter Transit If Free}

Question: Would you commute by transit (bus or train) more ofien if your employer offered you a free or subsidized pass?

\begin{tabular}{|lcc|} 
& Frequency & Percent of Respondents \\
\hline I commute by transit now & 1 & \\
My company offers it, but I don't use it & 1 & 0.3 \\
No, I would not change & 98 & 28.2 \\
I possibly would change to transit & 136 & 39.2 \\
I definitely would change to transit & 97 & 28.0 \\
Don't know & 15 & 4.3 \\
\hline
\end{tabular}

\section{Businesses that Transit Agencies Should Consider Part of Their Mission}

One obvious implication of the responses is that transit agencies need to be in the information business. Only about one out of four respondents $(24.3 \%)$ received information on public transit options from their employer (Table 28). A basic tenant of marketing is that one must be "aware" of a product before they can purchase or use it. Internet access appears to be one viable option in the effort to increase awareness of public transit services as 55.8 percent of the respondents have Internet access at home (Table 29) and 63.6 percent have it at work (Table 30).

For transit marketers, any paradigm shift must account for the dynamic nature of consumer communications. Websites and email have rapidly emerged as preferred communication options. Information dissemination is key to

\section{Table 24 \\ Parking Difficulty}

Question: How difficult is it to find a convenient parking space every workday that you drive?

\begin{tabular}{|lcc|}
\multicolumn{1}{c}{ Response } & Frequency & Percentage \\
\hline Very difficult & 19 & 5.4 \\
Somewhat difficult & 28 & 8.0 \\
Not at all difficult & 297 & 85.1 \\
Don't drive to work & 5 & 1.4 \\
\hline
\end{tabular}




\section{Table 25 \\ Work Parking Location}

Question: Where do you usually park for work?

\begin{tabular}{|lcc|}
\multicolumn{1}{c}{ Response } & Frequency & Percentage \\
\hline Lot or garage at your worksite & 323 & 92.3 \\
Within three blocks of your worksite & 23 & 6.6 \\
Further than three blocks from your worksite & 3 & 0.6 \\
Don't drive to work & 3 & 0.6 \\
\hline
\end{tabular}

\begin{tabular}{|ccc|}
\hline \multicolumn{3}{|c|}{ Table 26 } \\
Nearest Bus Stop-Residence \\
Question: Approximately how far is the nearest bus stop from your residence? \\
Response & Frequency & Percentage \\
\hline One block or less & 36 & 15.3 \\
1-2 blocks & 32 & 13.6 \\
3 or more blocks & 162 & 68.9 \\
Don't know & 5 & 2.1 \\
\hline
\end{tabular}

\begin{tabular}{|c|c|c|}
\hline \multicolumn{3}{|c|}{$\begin{array}{c}\text { Table 27 } \\
\text { Nearest Bus Stop-Work } \\
\text { Question: Approximately how far is the nearest bus stop from your work? }\end{array}$} \\
\hline Response & Frequency & Percentage \\
\hline One block or less & 127 & 47.7 \\
\hline 1-2 blocks & 61 & 22.9 \\
\hline 3 or more blocks & 78 & 29.3 \\
\hline Don't know & 0 & 0.0 \\
\hline
\end{tabular}

attracting and retaining customers in any industry. Not only can information technology become a key to building service awareness, innovative public transit managers must look to information technology as a way to extend their product before technology becomes a competitor. Telecommuting is increasingly popular. If transit does not embrace information technology, it may find itself at the wrong end of a competitive struggle. Can the daily commute be 


\section{Table 28}

\section{Transit Information Provided by Company}

Question: Has your employer ever given you or your coworkers information on carpooling, vanpooling, or public transportation?

\begin{tabular}{|lcc|}
\hline Response & Frequency & Percentage \\
\hline Yes & 83 & 24.3 \\
No & 255 & 74.6 \\
Don't know & 4 & 1.2 \\
\hline
\end{tabular}

\section{Table 29 \\ Internet Access-Home}

Question: Do you have access to the Internet at home?

\begin{tabular}{|lcc|} 
Response & Frequency & Percentage \\
\hline Yes & 192 & 55.8 \\
No & 151 & 43.9 \\
Don't know & 1 & 0.3 \\
\hline
\end{tabular}

\begin{tabular}{|ccc|}
\hline \multicolumn{2}{|c|}{$\begin{array}{c}\text { Table } 30 \\
\text { Internet Access-Work }\end{array}$} \\
Question: Do you have access to the Internet at work? \\
Response & Frequency & \\
\hline Yes & 218 & Percentage \\
No & 125 & 63.6 \\
Don't know & 0 & 36.4 \\
& & 0.0 \\
\hline
\end{tabular}

made more effective by providing access to technology? Some airports now have electronic service retailers who provide email, fax, word processing, and other electronic services. Airlines are also experimenting with such services. Could the bus or train of the future be equipped to provide similar services? Would this provide a sufficient motivation to attract and retain riders?

Another nontraditional option involves property development (Table 31). Transit property-based restaurants are identified by 88.1 percent of the respondents as a likely candidate for their patronage. Restaurants like TGI Fridays 
and Outback can now be found in facilities such as major league baseball parks and airport terminals that many thousands of individuals frequently visit. Public transit services have similar characteristics. Other facilities the study's respondents suggest for public transit centers include grocery stores (65.8\%), convenience stores $(64.1 \%)$, and bookstores $(63.5 \%)$. Still other popular options include dry cleaners (52.0\%) and exercise facilities (51.2\%). A third group includes educational facilities (45.5\%), office supply stores (42.3\%), and video stores $(39.4 \%)$. Child care comes in last at 21.5 percent.

The workday responsibilities and needs of transit users create the need for

\section{Table 31 \\ Worksite Facility Usage}

Question: If the following services were available within walking distance of your worksite, would you be likely to use any of the following before, after, or during your workday?

\begin{tabular}{|lllc|}
\multicolumn{1}{c}{ Facility } & Yes & No & Don't Know \\
\hline Bookstore & 63.5 & 28.7 & 7.7 \\
Convenience store & 64.1 & 32.8 & 3.2 \\
Educational facility & 45.5 & 48.7 & 5.8 \\
Grocery store & 65.8 & 31.0 & 3.2 \\
Restaurant/Eatery & 88.1 & 10.7 & 1.2 \\
Child care & 21.5 & 75.6 & 2.9 \\
Dry cleaners & 52.0 & 45.1 & 2.9 \\
Exercise facility & 51.2 & 44.8 & 4.1 \\
Office supply store & 42.3 & 55.1 & 2.6 \\
Video store & 39.4 & 57.1 & 3.5 \\
\hline
\end{tabular}

multiple-task trips and they currently represent a barrier to the use of public transit. Paying bills, eating lunch, and trips to the dry cleaners or grocery store often require off-property trips during breaks in the workday or on the way home. If banking and other services were available at a transit stop, would this also provide an incentive to use alternative transportation? Some transit properties have had success with day care, dry cleaning, and fast-food outlets. Are there other options that would remove such barriers to the use of public transit?

Is it possible for transit agencies to combine the electronic and property 
development options? Could electronic banking kiosks be provided in transit facilities? Electronic ordering of food and other products could be facilitated through software provided to frequent transit users as a benefit of their patronage. Items ordered could be delivered for pickup at designated transit stops.

\section{Analysis and Interpretation}

The crisis facing public transit agencies is both structurally and attitudinally based. The U.S. pattern of economic development and urban planning has generated urban sprawl and the family financial resources to support it. Households commonly have a vehicle for every family member able to drive. The number of individuals truly dependent on public transit for mobility has declined and the locations of jobs for such individuals often eliminate public transit as a practical alternative. Moreover, some public assistance programs now purchase cars for individuals.

Thus, it is a simple and well-established fact that most work commutes are now made in SOVs. More expensive gas has not reduced SOV commutes. Limits on spaces for parking and higher parking costs are unpopular options. Generating consumer dissatisfaction is seldom an effective long-term marketing strategy. Rather, the implication is that commuters need a positive incentive to motivate them to use public transit. Increasing the cost of alternatives through limited parking access or higher fees will not generate the customer satisfaction and loyalty needed to attract and retain customers.

\section{Implications for Shifting Public Transit's Existing Market Paradigm}

Benefit-based strategies should be a hallmark of the industry's paradigm shift. Information technologies, new services and amenities, and value-based pricing have the potential to enhance the market position of public transit.

\section{Quality-of-Life Issues}

What other options are available to transit agencies? Based on this study, it is evident that public transit does have options. Survey respondents are well educated and well paid, yet they expressed a willingness to use well-designed public transit services. They recognize traffic congestion as a problem, as they 
do air pollution. The link between the two is also acknowledged. The sampled commuters strongly indicate that reducing commutes is the solution to what are significant air quality problems. It is also apparent that the stress of commuting has an acknowledged impact on their quality of life. However, the respondents also suggest that the air quality issue does not affect them personally. The implications for transit marketers is that there is a need for efforts that:

- reinforce the link between the stress of commuting and one's quality of life;

- link traffic congestion, air quality, and life quality; and

- establish that air quality has a personal effect on commuters.

These relationships are captured in Figure 1.

\section{Market Segmentation}

The results summarized in Table 1 are indicative of the changing target markets for transit services. What is immediately apparent is the income and educational profile of the commuters within the area studied. Nearly one-third of the commuters sampled (32.1\%) report an income of $\$ 70,000+$. In contrast, only 2.6 percent have a household income of less than $\$ 20,000$. Fully 56.4 percent have at least a college degree. Fifty-six percent (56.4\%) are employed as either executives/managers/professionals or administrators/technicians. This area's commuters are generally using transit by choice, not out of necessity.

The implication is rather clear. If public transit agencies want to attract and retain such commuters, they cannot do so with cost-based, utilitarian services. High-profile consumers such as these commuters are interested in product benefits. To be attracted to public transit, they must see tangible benefits over their existing transit mode (normally an SOV). If public transit properties cannot provide something that their SOV does not, they will not become a transit rider.

What are their options? The transit property can provide a driver and a vehicle, or they can provide freedom from stress, better air quality for the commuter's family, convenient access to needed services, additional leisure or work time, and maybe even a little "fun." The challenge is to change their man- 


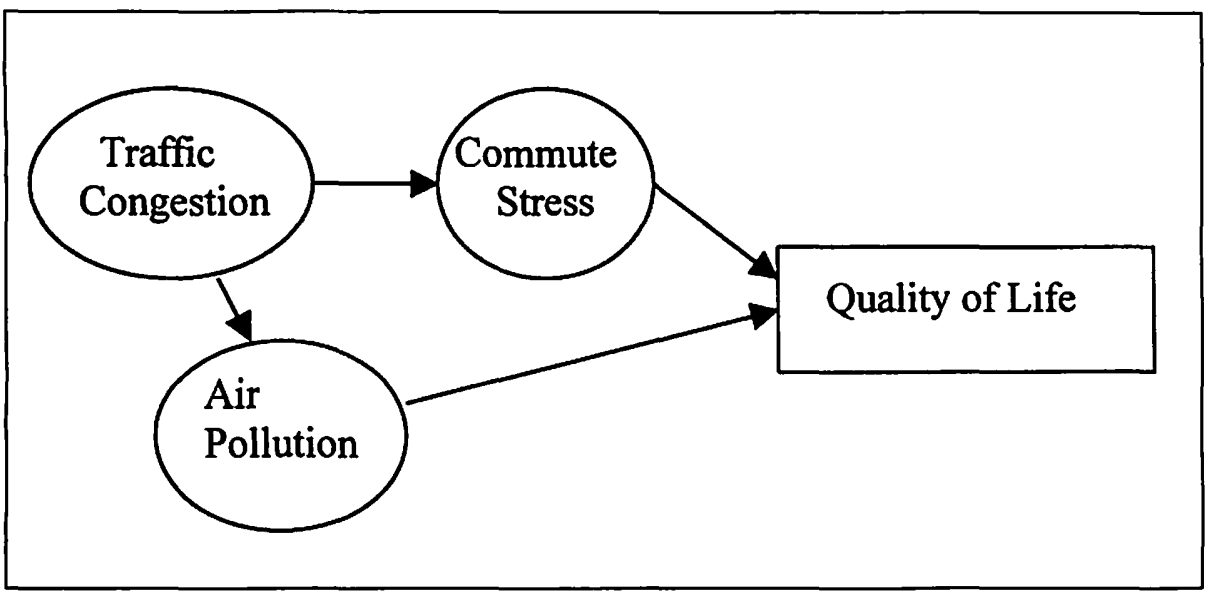

Figure 1. Quality-of-life issues

agement paradigm from an "operational" perspective to a more "customerfocused," market-based approach that embraces such market-driven strategies.

\section{Multiple-Mode Options}

The multiple-trip purposes revealed in the survey responses also call for a more comprehensive product offering. In Europe, the new public transit paradigm views a public transit property as a transportation facilitator rather than a transit provider. The facilitator agency provides not only the standard commute options, but also a neighborhood SOV should the rider need one. They also extend trip planning, and even car purchasing, assistance if required.

In the United States, at least one vanpooling operation is owned by a car rental firm. Why consider the two separate operations? A 4-passenger carpool may not be as efficient as a 9- or 11-passenger vanpool, but it is better than four SOVs. New management paradigms for the public transit industry must accommodate such trade-offs. Just as the freight-carrying portion of the transportation industry long ago discovered the benefits of multimodal solutions, commuter transit properties must accommodate similar needs. If a transit user drives his or her car to a station or stop, and then takes the bus or train, is it not a multimodal trip? Could a carpool, vanpool, taxi, or small bus make this system even more efficient? Diversified transit planning must become a cornerstone of the new transit paradigm. 


\section{Retail Property Development}

Many of the country's transit properties have vast land holdings that lie in prime shopping areas. They also have a large number of "captured" customers. One needs only to go to Europe to find examples. In Paris, there is a multilevel underground shopping mall at one of the main downtown transit stations. All the shopping needs of commuters are satisfied in one location, all by wellknown retail outlets.

In essence, public transit properties can become property managers or retail operators. Given their lack of experience in retail, the former appears to be the more prudent choice. Either way, a benefit is provided to transit riders, and a barrier to use is eliminated. An opportunity for additional operating capital is also inherent in this strategy.

\section{Value-Generating Strategies}

The core benefit that needs to be stressed through public transit's new management paradigm is value. Value is simply the ratio of product benefits to costs. The relevant costs include the dollar cost of the service, plus the time and effort required to use the service. Only in a few cases, in large metro areas such as New York City with high land values, can transit be sold on purely economic grounds. Even then, there is at least some debate as to whether the price of the parking space or the time spent finding it is the greatest cost.

The benefits provided by technology, facilitating multiple-mode trips, and retail shopping opportunities can increase the value of transit services to today's upscale commuter more than any price discount. Even "free" transit is often not used because of the barriers to its use; that is, it is simply not convenient to use. Reducing stress and improving air quality can add value to one's life. Commuters need to be educated about transit's role in this value-enhancing process.

\section{Conclusions}

Public transit managers have a unique opportunity to redefine their industry. If they fail to do so, all indications are that its market share will continue its decline and the industry crisis will slowly become a catastrophe. The industry simply has not kept pace with changes in the marketplace. Cars continue to 
grow more luxurious; public transit services do not. Public transit continues an emphasis on cost control and abatement when many customers are searching for comfort and convenience.

Currently, public transit is not a good fit with upscale markets such as the one investigated in this study. The markets have moved; the train and bus lines have not. Fewer and fewer U.S. consumers are driven to use public transportation by necessity. New-millennium commuters generally want value-added services, yet transit properties continue to stress low prices and discounts. Most consumers have a car, and it is considered a sunk cost. The only variable cost of note is gas. Public transit properties cannot operate more efficiently than a car in the mind of the car owner who has to make a payment whether he or she drives or rides the train or bus.

However, transit does have benefits unavailable to SOVs. The commuter does not have to drive. The commuter can work or relax, and does not have to worry about bad drivers. He or she can read or talk on their cellular phone with no fear of an accident. They might even find someone interesting with whom to interact. The stress of commuting can be reduced, and air quality enhanced. Is the value such benefits contribute to one's quality of life sufficient to motivate a shift from the SOV to public transit? It is a question that deserves the attention of transit managers.

No matter the perceived benefit, the major point is that public transit organizations must find ways to increase the value of their services. The current study suggests several courses of action. Others will come to mind. Nevertheless, the key component in public transit's paradigm shift must be the exchange of the cost-minimization approach to strategic decision making, to one of benefit maximization. Otherwise the industry will continue to lose market share. The new-millennium transit rider searches for value. The key for public transit properties in their efforts to attract and retain riders is to create services that have sufficient value to motivate consumers to leave their SOVs. Public transit's marketing strategies must originate with the needs and wants of consumers, not with the needs and wants of operations personnel.

To deny the need for a paradigm shift is to ignore the reality of the new- 
millennium marketplace. Recently, the International Taxi and Livery Association sponsored its first marketing seminar. Already, these private sector alternative transportation providers are diversifying their services in response to consumer demands. Where there once were taxis, today these firms operate taxis, executive sedans, and limos-different products performing essentially the same function, but for different market segments. To these services, many taxi operators have added airport shuttles and executive coaches. The really innovative operators now have contracts to provide concierge services in hotels and operate destination-management companies. They can literally book your flight and lodging, transport you from the airport to your hotel whether you are an individual or a group in the thousands, arrange theme parties and transport you to them, and then get you back to the airport for your flight home. And, while you are in town, if you'd like to check with the concierge, a special dinner can be arranged for you and yours along with a ride to the restaurant in one of their taxis, executive sedans, or limos! Is this a successful paradigm shift? You had better believe it is!

\section{Endnote}

1. The product life cycle (PLC) suggests that all products, both goods and services, go through a process that begins with their introduction to the market. The PLC is comprised of four basic stages: introduction, growth, maturity, and decline. The maturity stage is often broken into two separate stages-early maturity and late maturity.

\section{References}

Daft, Richard, Robert Lengel, and Glen Perdue. April 1998. Creating a new future for public transportation: TCRP's strategic road map. Results Digest 24, Washington, DC: Transit Cooperative Research.

Kotler, Phillip. 1997. Marketing management: Analysis, planning, implementation, and control. Upper Saddle River, NJ: Prentice Hall.

\section{About the Authors}

J. JOSEPH CRONIN (jcronin@cob.fsu.edu) is the director of education and training at Florida State University's Marketing Institute. His primary research 
interests are in the areas of service quality and customer satisfaction, particularly as applied to sports, public transit, and managed health care issues.

Dr. Cronin's work has appeared in numerous publications, and he has served as a member of the editorial review board for several trade journals. In addition, he serves as a review committee member for the Transit Cooperative Research Program, administered by the National Academy of Sciences and the Transportation Research Board, and the Center for Clean Air Policy Public Transit Repositioning Dialogue Group.

Roscoe Hightower, JR. (rhighto@uakron.edu) is an assistant professor of marketing at the University of Akron's College of Business Administration where he teaches sales management and service marketing. He received a Ph.D. in marketing from Florida State University in 1997. Dr. Hightower worked as a client executive for IBM after obtaining bachelor's and master's degrees from Florida A\&M University. His research interests lie in the interface between public transportation and marketing topics. His research has been published in the Journal of Services Marketing and several professional proceedings. 